JURNAL GIZI DAN DIETETIK INDONESIA

Vol. 4, No. 2, Mei 2016: 81-87
Tersedia online pada: http://ejournal.almaata.ac.id/index.php/IJND DOI : http://dx.doi.org/10.21927/ijnd.2016.4(2).81-87

\title{
Jajanan tradisional jawa meningkatkan kadar gula darah pasien diabetes mellitus tipe 2 rawat jalan di RSUD Panembahan Senopati Bantul
}

\author{
Java traditional snacks increased blood glucose level among patients with type 2 diabetes mellitus \\ in Panembahan Senopati Bantul Hospital
}

Febri Nirnawati ${ }^{1}$, Esti Nurwanti ${ }^{1}$, Isti Suryani ${ }^{2}$

\begin{abstract}
Background: Yogyakarta is province in Indonesia with the highest prevalence of diabetes mellitus (DM) (2.6\%). Blood sugar levels in diabetic patients tend to be high. One cause of the increase in blood sugar levels is the intake of traditional snacks. Energy intake and sucrose that consist of traditional snacks can increase blood sugar levels in diabetic patients.

Objectives: To determine the relationship between the intake of traditional snacks with blood sugar levels among patients with type 2 DM in Panembahan Senopati Bantul Hospital.

Methods: This was an observational study with cross sectional design. The study population was all patients with type 2 DM outpatient in Panembahan Senopati Bantul Hospitals. This included 89 samples who meet the inclusion and exclusion criteria. The sampling method was purposive sampling. The patient's weight was measured by using a digital bathroom scales to the nearest $0.1 \mathrm{~kg}$ and height was measured using microtoice to the nearest $0.1 \mathrm{~cm}$ assisted by trained enumerators. Data of intake frequency, energy intake, and sucrose from traditional snacks were obtained by using a semi-quantitative food frequency questionnaire (SQFFQ). Data were analyzed using univariate analysis (descriptive) and bivariate (Fisher's exact test).

Results: The analysis Fisher's exact test showed that there was significant relationship between sucrose intake ( $p=0.024)$, energi $(p=0.021)$, and frequency $(p=0.046)$ consumption of traditional snacks with blood sugar levels of patients with type 2 DM in Panembahan Senopati Bantul Hospital.

Conclusions: Consumption of traditional snacks had a significant association with the rise in blood sugar levels in patients with type 2 DM.
\end{abstract}

KEYWORDS: traditional snacks, blood sugar levels, diabetes mellitus (DM)

\begin{abstract}
ABSTRAK
Latar belakang: Prevalensi diabetes mellitus (DM) tertinggi di Indonesia terdapat di DI Yogyakarta (2,6\%). Kadar gula darah pada pasien DM cenderung tinggi. Salah satu penyebab kenaikan kadar gula darah yaitu asupan jajanan tradisional. Asupan energi dan sukrosa yang berlebih dari jajanan tradisional dapat meningkatkan kadar gula darah pada pasien DM.

Tujuan: Mengetahui hubungan antara asupan jajanan tradisional dengan kadar gula darah pasien DM tipe 2 rawat jalan di RSUD Panembahan Senopati Bantul.

Metode: Penelitian ini merupakan penelitian observasional dengan rancangan cross sectional. Populasi penelitian adalah semua pasien DM tipe 2 rawat jalan di RSUD Panembahan Senopati Bantul. Sampel penelitian berjumlah 89 orang yang memenuhi kriteria inklusi dan eksklusi. Metode pengambilan sampel yang digunakan yaitu purposive sampling. Berat badan pasien diukur dengan menggunakan timbangan injak digital dengan ketelitian 0,1 kg, sedangkan tinggi badan diukur menggunakan microtoice dengan ketelitian 0,1 cm yang dibantu oleh enumerator terlatih. Data frekuensi asupan, asupan energi dan sukrosa dari jajanan tradisional diperoleh menggunakan semi quantitative food frequency questionnaire (SQFFQ). Data dianalisis menggunakan analisis univariat (deskriptif) dan bivariat (fisher's exact test).
\end{abstract}

1Prodi S1 IImu Gizi Universitas Alma Ata Yogyakarta, Jl. Ring Road Barat Daya No.1, e-mail: febrinirnas@gmail.com

2Jurusan Gizi, Poltekkes Kemenkes Yogyakarta, Jl. Tata Bumi No. 3, Banyuraden, Gamping, Sleman, Yogyakarta 
Hasil: Hasil analisis Fisher's exact test menunjukkan terdapat hubungan yang signifikan antara asupan sukrosa $(p=0,024)$, energi $(p=0,021)$, dan frekuensi $(p=0,046)$ konsumsi jajanan tradisional dengan kadar gula darah pasien DM tipe 2 di RSUD Panembahan Senopati Bantul

Kesimpulan: Konsumsi jajanan tradisional memiliki hubungan yang signifikan dengan kenaikan kadar gula darah pada pasien DM tipe 2.

KATA KUNCI : jajanan tradisional, kadar gula darah, diabetes mellitus (DM)

\section{PENDAHULUAN}

Diabetes mellitus (DM) tipe 2 merupakan $90 \%$ dari kasus DM yang dulu dikenal sebagai non insulin dependent diabetes mellitus (NIDDM). Bentuk DM ini bervariasi mulai dari yang dominan resistensi insulin, defisiensi insulin relatif sampai defek sekresi insulin. Pada kondisi diabetes ini terjadi penurunan kemampuan insulin untuk bekerja di jaringan perifer (insulin resistance) dan disfungsi sel $\beta$ (1).

World Health Organization (WHO) melaporkan bahwa DM semakin berkembang dan menjadi ancaman masyarakat dunia (2). Sebesar $90 \%$ penderita DM di dunia termasuk dalam klasifikasi DM tipe 2. Prevalensi penderita DM tipe 2 di seluruh dunia sebesar 285 juta $(6,4 \%)$ pada tahun 2010 dan akan meningkat menjadi 439 juta $(7,7 \%)$ pada tahun 2030. WHO juga memastikan bahwa peningkatan penderita DM tipe 2 paling banyak terjadi di negara berkembang seperti Indonesia. Indonesia menempati urutan ke-4 tertinggi di dunia setelah India, Cina, dan Amerika serikat (3).

Jumlah penyakit DM di Indonesia tahun 2000 mencapai 8,43 juta jiwa dan diperkirakan mencapai 21,257 juta jiwa pada tahun 2030. Berdasarkan data Departemen Kesehatan (Depkes), angka prevalensi penyakit DM di Indonesia pada tahun 2008 mencapai $5,7 \%$ dari jumlah penduduk Indonesia atau sekitar 12 juta jiwa. Penyakit DM terdiri dari DM tipe 1 dan DM tipe 2 masuk dalam kategori penyakit tidak menular. Penyakit DM tipe 2 merupakan salah satu penyebab utama kematian atau sekitar 2,1\% dari seluruh kematian. Jumlah penyakit DM tipe 2 semakin meningkat pada kelompok umur dewasa terutama umur 30 tahun (4).

Prevalensi diabetes yang terdiagnosis dokter tertinggi terdapat di DI Yogyakarta $(2,6 \%)$, yang diikuti oleh DKI Jakarta (2,5\%), Sulawesi Utara $(2,4 \%)$, dan Kalimantan Timur (2,3\%). Prevalensi diabetes yang terdiagnosis dokter atau gejala, tertinggi terdapat di Sulawesi Tengah $(3,7 \%)$, yang diikuti oleh Sulawesi Utara (3,6\%), Sulawesi Selatan (3,4\%), dan Nusa Tenggara Timur (3,3 persen). Prevalensi DM berdasarkan diagnosis dokter dan gejala meningkat sesuai dengan bertambahnya umur, namun mulai umur $\geq 65$ tahun cenderung menurun (5).

Salah satu faktor yang menyebabkan DM yaitu frekuensi konsumsi gula berlebih. Jajanan tradisional yang terdapat di Yogyakarta cenderung mengandung tinggi gula contohnya wajik, gaplek, yangko, cendol, cincau, cenil, dan klepon. Karbohidrat sederhana yang terdapat pada jajanan tradisional merupakan jenis karbohidrat yang mudah diubah menjadi glukosa, sehingga karbohidrat ini sangat cepat meningkatkan kadar glukosa darah. Produk pangan seperti itu disebut sebagai empty calorie, karena hanya memberikan energi (kalori) bagi tubuh tetapi tidak menyuplai vitamin maupun mineral. Di dalam tubuh, karbohidrat sederhana diubah menjadi gula sederhana atau glukosa yang larut dalam aliran darah, sehingga menyebabkan kadar glukosa darah meningkat dan turun dengan cepat. Keadaan ini berbahaya bagi penyakit DM tipe 2 (6).

Dari hasil studi pendahuluan di RSUD Panembahan Senopati Bantul didapatkan jumlah keseluruhan pasien DM sebanyak 1.530 orang pada tahun 2014 dan jumlah pasien DM tipe 2 sebanyak 1.206 orang. Dari hasil wawancara yang dilakukan di RSUD Panembahan Senopati Bantul pasien diabetes tipe 2 setiap bulannya diperkirakan 157 orang (7). Tujuan penelitian ini adalah mengetahui hubungan antara asupan jajanan tradisional dengan kadar gula darah pasien DM tipe 2 rawat jalan di RSUD Panembahan Senopati Bantul. 


\section{BAHAN DAN METODE}

Jenis penelitian ini merupakan penelitian kuantitatif dengan rancangan cross sectional. Penelitian ini dilakukan di Poli Rawat Jalan RSUD Panembahan Senopati Bantul pada bulan Januari 2016. Berdasarkan data pasien tahun 2014, Poli Rawat Jalan RSUD Panembahan Senopati memiliki pasien DM tipe 2 sebanyak 1.206 orang.

Populasi pada penelitian ini adalah seluruh pasien rawat jalan yang terdiagnosis DM tipe 2 di RSUD Panembahan Senopati Bantul. Subjek penelitian ini adalah subjek yang memenuhi kriteria inklusi yaitu pasien kontrol yang telah terdiagnosis DM tipe 2 yang diketahui berdasarkan catatan rekam medis, dan bisa berkomunikasi dengan baik berdasarkan pengamatan. Pemilihan subjek penelitian dengan purposive sampling.

Variabel independen adalah asupan energi, sukrosa, dan frekuensi konsumsi jajanan tradisional sedangkan variabel dependen adalah kadar gula darah puasa. Data karakteristik subjek diperoleh melalui wawancara langsung dengan bantuan kuesioner yang meliputi nama, alamat, umur, jenis kelamin, pendidikan, serta pekerjaan. Data dikumpulkan oleh dua enumerator dengan kualifikasi S1 Gizi yang telah dilatih. Sebelum dilakukan penelitian, subjek diberikan penjelasan mengenai tujuan penelitian. Apabila subjek menyetujui menjadi responden, maka subjek dapat mengisi dan menandatangani surat pernyataan yang telah dibuat oleh peneliti. Semua data subjek penelitian dijaga kerahasiaanya oleh peneliti.

Data asupan energi dan sukrosa dari jajanan tradisional serta frekuensi konsumsi jajanan tradisional dikumpulkan melalui wawancara menggunakan formulir semi quantitative food frequency questionaire (SQFFQ) yang sebelumnya telah diujicobakan dan diuji validitas dengan hasil semua data valid dan reliabilitasnya tinggi. Asupan energi dari jajanan tradisional dikategorikan baik jika asupan energi tidak melebihi 30\% total kalori. Cutt off ini diambil berdasarkan anjuran energi dari snack/selingan dalam sehari yaitu $30 \%$ dari total kalori. Asupan sukrosa dari jajanan tradisional dikategorikan baik jika asupan sukrosa tidak melebihi $5 \%$ total kalori. Cut off ini ditentukan berdasarkan Perkumpulan Endokrinologi Indonesia (PERKENI) yang menyatakan bahwa kebutuhan gula pada pasien DM $<5 \%$ total kalori dalam sehari (4). Frekuensi konsumsi jajanan tradisional dikategorikan berdasarkan rata-rata frekuensi konsumsi jajanan tradisional dari seluruh subjek penelitian. Berdasarkan rata-rata konsumsi jajanan tradisional, diketahui bahwa subjek penelitian mengonsumsi jajanan tradisional 7x/minggu. Kadar gula darah puasa dikategorikan tinggi jika $\geq 126$ $\mathrm{mg} / \mathrm{dL}$.

Uji statistik yang digunakan adalah Fisher's exact test untuk melihat hubungan antara asupan energi, sukrosa, dan frekuensi konsumsi jajanan tradisional dengan kadar gula darah. Uji ini diambil karena ada cell dengan frekuensi harapan kurang dari 5.

\section{HASIL}

\section{Karakteristik subjek penelitian}

Berdasarkan Tabel 1 subjek pada penelitian ini terdiri dari 89 orang pasien DM tipe 2 rawat jalan di RSUD Panembahan Senopati Yogyakarta. Sebagian besar pasien DM tipe 2 pada penelitian ini memiliki kadar gula darah tinggi yaitu 84 orang $(94,4 \%)$. Sebagian besar subjek penelitian berusia $>50$ tahun $(67,4 \%)$, berjenis kelamin perempuan $(62,9 \%)$, pendidikan terakhir SD $(33,7 \%)$, dan pekerjaan ibu rumah tangga $(32,6 \%)$.

\section{Jenis jajanan tradisional}

Berdasarkan Tabel 2 subjek dengan kadar gula darah tinggi cenderung mengonsumsi jajanan tradisional lebih sering dibandingkan dengan pasien dengan kadar gula darah normal. Subjek dengan kadar gula darah tinggi mengonsumsi peyek $5 \mathrm{x} /$ minggu, bakpia 1x/minggu, mata kebo, tiwul, getuk, nagasari, onde-onde, kue lapis, dan growol $3 x /$ minggu, dan grontol $5 x /$ minggu.

\section{Frekuensi asupan jajanan tradisional}

Berdasarkan Tabel 3 dari semua subjek sebagian besar memiliki frekuensi asupan sering ( $\geq 7 \mathrm{kali} / \mathrm{minggu}$ ) yaitu $80,9 \%$. Dari asupan sukrosa sebagian besar memiliki asupan tidak baik ( $\geq 5 \%$ ) 
Tabel 1. Distribusi frekuensi karakteristik subjek penelitian

\begin{tabular}{|c|c|c|}
\hline Kategori & $\mathbf{n}$ & $\begin{array}{c}\text { Persentase } \\
(\%)\end{array}$ \\
\hline \multicolumn{3}{|l|}{ Umur } \\
\hline 30-49 tahun & 29 & 32,6 \\
\hline$>50$ tahun & 60 & 67,4 \\
\hline Jumlah & 89 & 100 \\
\hline \multicolumn{3}{|l|}{ Jenis kelamin } \\
\hline Laki-laki & 33 & 37,1 \\
\hline Perempuan & 56 & 62,9 \\
\hline Jumlah & 89 & 100 \\
\hline \multicolumn{3}{|l|}{ Pendidikan } \\
\hline Tidak sekolah & 9 & 10,1 \\
\hline Tamat SD & 30 & 33,7 \\
\hline Tamat SMP & 25 & 28,1 \\
\hline Tamat SMA/SMK & 18 & 20,2 \\
\hline Tamat perguruan tinggi & 7 & 7,9 \\
\hline Jumlah & 89 & 100 \\
\hline \multicolumn{3}{|l|}{ Pekerjaan } \\
\hline Buruh & 21 & 23,6 \\
\hline Pedagang/ wiraswasta & 18 & 20,2 \\
\hline Petani & 5 & 5,6 \\
\hline Nelayan & 1 & 1,1 \\
\hline Pegawai perusahaan swasta & 3 & 3,4 \\
\hline PNS/TNI/POLRI & 3 & 3,4 \\
\hline Pensiunan & 9 & 10,1 \\
\hline Lain-lain/IRT & 29 & 32,6 \\
\hline Jumlah & 89 & 100 \\
\hline \multicolumn{3}{|l|}{ Kadar gula darah puasa } \\
\hline Tinggi ( $\geq 126$ mg/dL) & 84 & 94,4 \\
\hline Normal (<126 mg/dL) & 5 & 5,6 \\
\hline Jumlah & 89 & 100 \\
\hline
\end{tabular}

yaitu $70,8 \%$. Dilihat dari asupan energi sebagian besar juga memiliki asupan tidak baik $(\geq 30 \%)$ yaitu $85,4 \%$.

\section{Hubungan asupan jajanan tradisional dengan kadar gula darah}

Berdasarkan Tabel 4 pada kelompok subjek dengan kadar gula darah tinggi, persentase yang mengonsumsi energi berlebih dari jajanan tradisional ( $\geq 30 \%$ total kalori) mencapai $97,37 \%$, mengonsumsi sukrosa berlebih dari jajanan tradisional ( $\geq 5 \%$ total kalori) mencapai $98,4 \%$, dan frekuensi konsumsi $\geq 7$ kali/minggu mencapai $97,23 \%$. Setelah diuji secara statistik dengan uji Fisher's exact test menunjukkan adanya hubungan yang signifikan antara asupan energi, asupan sukrosa, dan frekuensi konsumsi jajanan tradisional dengan kadar gula darah dengan nilai $p<0,05$.

\section{BAHASAN}

\section{Karakteristik subjek penelitian}

Sebagian besar pasien DM tipe 2 pada penelitian memiliki kadar gula darah tinggi yaitu 84 orang $(94,4 \%)$. Sebagian besar subjek penelitian berusia $>50$ tahun $(67,4 \%)$, berjenis kelamin perempuan $(62,9 \%)$, pendidikan terakhir

Tabel 2. Karakteristik jajanan tradisional yang paling sering dikonsumsi subjek penelitian

\begin{tabular}{|c|c|c|c|c|c|}
\hline \multirow{3}{*}{$\begin{array}{l}\text { Jenis jajanan } \\
\text { tradisional }\end{array}$} & \multirow{2}{*}{\multicolumn{2}{|c|}{$\begin{array}{c}\text { Rata-rata frekuensi konsumsi } \\
\text { jajanan tradisional/minggu } \\
\text { Kadar gula darah subjek }\end{array}$}} & \multirow{3}{*}{ Takaran Saji (gram) } & \multirow{2}{*}{\multicolumn{2}{|c|}{$\begin{array}{l}\text { Kandungan zat gizi } \\
\text { (per takaran saji) }\end{array}$}} \\
\hline & & & & & \\
\hline & Normal & Tinggi & & Energi (kkal) & Sukrosa (gram) \\
\hline \multicolumn{6}{|l|}{ Jajanan kering } \\
\hline Peyek & 3 & 5 & 28 & 44 & 4,62 \\
\hline Bakpia & 1 & 1 & 25 & 78,09 & 4,7 \\
\hline \multicolumn{6}{|l|}{ Jajanan basah } \\
\hline Mata kebo & 2 & 3 & 45 & 105,1 & 26 \\
\hline Tiwul & 2 & 3 & 150 & 315,99 & 33,6 \\
\hline Getuk & 2 & 3 & 70 & 141 & 9,3 \\
\hline Nagasari & 1 & 3 & 175 & 275 & 16,6 \\
\hline Onde-onde & 2 & 3 & 85 & 200 & 20,9 \\
\hline Kue lapis & 2 & 3 & 100 & 388 & 24,3 \\
\hline Grontol & 4 & 5 & 100 & 141,5 & 26 \\
\hline Growol & 2 & 3 & 175 & 284,3 & 26 \\
\hline
\end{tabular}

(Waspadji dkk, 2011, Lestari dkk, 2014, Nutrisurvey) 
Tabel 3. Analisis univariat asupan jajanan tradisional

\begin{tabular}{lcc}
\hline \multicolumn{1}{c}{ Kategori } & N & Persentase (\%) \\
\hline Frekuensi asupan jajanan tradisional & & \\
$\quad$ Tidak sering (<7 kali/minggu) & 17 & 19,1 \\
Sering( $\geq 7$ kali/minggu ) & 72 & 80,9 \\
Jumlah & 89 & 100 \\
Asupan sukrosa dari jajanan tradisional & & \\
Baik (<5\% total kalori ) & 26 & 29,2 \\
Tidak baik ( $\geq 5 \%$ total kalori) & 63 & 70,8 \\
Jumlah & 89 & 100 \\
Asupan energi total dari jajanan tradisional & & \\
baik (<30\% total kalori) & 13 & 14,6 \\
Tidak baik ( $\geq 30 \%$ total kalori ) & 76 & 85,4 \\
Jumlah & 89 & 100 \\
\hline
\end{tabular}

Tabel 4. Analisis hubungan antara asupan jajanan tradisional dengan kadar gula darah

\begin{tabular}{|c|c|c|c|c|c|}
\hline \multirow{3}{*}{ Variabel } & \multicolumn{4}{|c|}{ Kadar gula darah } & \multirow{3}{*}{$\mathbf{p}$} \\
\hline & \multicolumn{2}{|c|}{ Normal } & \multicolumn{2}{|c|}{ Tinggi } & \\
\hline & $\mathbf{N}$ & $\%$ & $\mathbf{n}$ & $\%$ & \\
\hline \multicolumn{6}{|c|}{ Asupan energi dari jajanan tradisional } \\
\hline Baik (<30\% total kalori) & 3 & 23,08 & 10 & 76,92 & $0,021^{*}$ \\
\hline Tidak baik ( $\geq 30 \%$ total kalori) & 2 & 2,63 & 74 & 97,37 & \\
\hline \multicolumn{6}{|c|}{ Asupan Sukrosa dari jajanan tradisional } \\
\hline Baik $(<5 \%$ total kalori) & 4 & 15,4 & 22 & 84,6 & $0,024^{*}$ \\
\hline Tidak baik ( $\geq 5 \%$ total kalori) & 1 & 1,6 & 62 & 98,4 & \\
\hline \multicolumn{6}{|c|}{ Frekuensi Asupan jajanan tradisional } \\
\hline Tidak sering( $<7$ kali/minggu $)$ & 3 & 17,64 & 14 & 82,36 & $0,046^{*}$ \\
\hline Sering ( $\geq 7$ kali/minggu) & 2 & 2,77 & 70 & 97,23 & \\
\hline
\end{tabular}

* Signifikan $(p<0,05)$

SD $(33,7 \%)$, dan pekerjaan ibu rumah tangga $(32,6 \%)$.

Hal ini dapat terjadi karena keadaan ini lebih memungkinkan ibu yang berprofesi sebagai ibu rumah tangga dan berpendidikan rendah mengonsumsi makanan tradisional dengan kandungan kalori dan sukrosa yang tinggi. Jajanan tradisional lebih mudah didapatkan di dekat rumah/ acara syukuran, harganya murah, dan banyak disukai oleh masyarakat.

\section{Hubungan antara asupan energi dari jajanan tradisional dengan kadar gula darah}

Hasil uji (Tabel 4) menunjukkan bahwa terdapat hubungan yang signifikan antara asupan energi yang berasal dari jajanan tradisional dengan kadar gula darah $(p<0,05)$. Hal ini karena anjuran asupan energi yang berasal dari snack/jajanan sebaiknya $<30 \%$ dari total energi. Namun demikian, sebagian besar subjek penelitian mengonsumsi jajanan tradisional $\geq 30 \%$ total kalori sehingga risiko kadar gula darah tinggi pada pasien DM semakin meningkat. Tidak terkendalinya kadar gula darah pada pasien DM dapat disebabkan oleh asupan energi/kalori melebihi kebutuhan yang dianjurkan bagi pasien DM, dan rendahnya reseptor hormon insulin di permukaan sel yang berfungsi untuk membantu glukosa masuk ke dalam sel sehingga mampu menuju sel-sel organorgan yang membutuhkan (3). Hasil penelitian ini sejalan dengan penelitian di Kalimantan Timur tentang hubungan pola makan dengan tingkat gula darah yang mengemukakan bahwa ada hubungan yang signifikan antara asupan energi dengan kadar gula darah (8). 


\section{Hubungan antara asupan sukrosa dari jajanan tradisional dengan kadar gula darah}

Asupan sukrosa dari jajanan tradisional dan kadar gula darah juga memiliki hubungan yang signifikan. Berdasarkan PERKENI, asupan sukrosa pada pasien DM sebaiknya $<5 \%$ total kalori. Namun, sebagian besar subjek penelitian mengonsumsi sukrosa lebih dari $5 \%$ total kalori. Padahal asupan sukrosa yang diteliti hanya sukrosa yang berasal dari jajanan tradisional. Penelitian ini belum menghitung asupan sukrosa total yang berasal dari berbagai sumber bahan makanan yang dikonsumsi subjek penelitian dalam satu hari. Oleh karena itu, subjek dengan asupan sukrosa melebihi dari kebutuhan, kadar gula darahnya mengalami peningkatan.

Hasil penelitian ini sejalan dengan penelitian yang telah dilakukan di Kelurahan Gedawang Kecamatan Banyumanik Kota Semarang yang menyatakan bahwa terdapat hubungan antara asupan karbohidrat sederhana dengan kadar glukosa darah pada pasien DM tipe 2 wanita usia 45-55 tahun (9). Sukrosa mengandung tinggi energi yang mudah diserap oleh usus untuk digunakan sebagai energi serta diubah menjadi glikogen dan lemak yang disimpan di hati dan jaringan lemak. Konsumsi karbohidarat dalam bentuk jajanan tidak menimbulkan rasa puas seperti karbohidrat lain yang mengandung tinggi energi sehingga meningkatkan frekuensi konsumsinya.

\section{Hubungan antara frekuensi konsumsi jajanan tradisional dengan kadar gula darah}

Frekuensi konsumsi jajanan tradisional dan kadar gula darah memiliki hubungan yang signifikan. Sebagian besar subjek penelitian yang mengonsumsi jajanan tradisional lebih dari rata-rata konsumsi seluruh subjek penelitian ( $>7 \mathrm{x} / \mathrm{minggu}$ ) dan memiliki kadar gula darah yang tinggi.

Pada penelitian ini frekuensi dapat mengindikasikan semakin sering mengonsumsi makanan jajanan maka kadar gula darah semakin tinggi. Namun demikian, frekuensi saja belum cukup menggambarkan jumlah asupan yang adekuat dan sesuai dengan petunjuk konsumsi makanan pada penderita DM meliputi jumlah, jenis, dan jadwal (3J). Sehingga banyaknya frekuensi konsumsi jajanan tradisional menandakan kualitas diet yang kurang tepat. Selain memperhatikan pola 3J, kualitas diet yang baik pada pasien DM dapat diperbaiki melalui konseling gizi individu. Sebagai contoh, kualitas diet pasien DM di RSUP Dr. Sardjito dapat diperbaiki melalui konseling gizi individu (10).

\section{KESIMPULAN DAN SARAN}

Pada penelitian ini didapatkan ada hubungan yang signifikan antara asupan energi, sukrosa dan frekuensi konsumsi jajanan tradisional dengan kadar gula darah pada pasien DM tipe 2. Sebagian besar subjek penelitian dengan asupan energi, sukrosa, dan frekuensi konsumsi jajanan tradisional yang berlebih memiliki kadar gula darah yang tinggi. Makanan yang sering dikonsumsi subjek penelitian yaitu peyek, bakpia, mata kebo, tiwul, getuk, nagosari, onde-onde, kue lapis, grontol, dan growol.

Hasil penelitian ini merekomendasikan kepada pihak rumah sakit untuk memberikan pendidikan gizi (konseling) untuk meningkatkan pengetahuan gizi kepada pasien DM tentang kandungan energi dan sukrosa yang terdapat pada jajanan tradisional.

\section{RUJUKAN}

1. Adam. Klasifikasi dan kriteria diabetes mellitus yang baru. Jakarta: Cermin Dunia Kedoketran; 2010.

2. WHO. Diabetes mellitus [Internet]. 2010 [cited 2015 Jun 1]. Available from: http//www.who.int. com

3. Suyono. Kecenderungan peningkatan jumlah pasien diabetes. Jakarta: FKUI; 2011.

4. PERKENI. Konsesus pengolahan diabetes melitus tipe 2 di Indonesia. Jakarta: PERKENI; 2011.

5. Badan Penelitian dan Pengembangan Kesehatan Republik Indonesia. Riset kesehatan dasar 2013. Jakarta: Badan Penelitian dan Pengembangan Kesehatan RI; 2013.

6. Maulana M. Diabetes mellitus. Yogyakarta: Kata Hati; 2010.

7. Bagian Rekam Medis RSUD Panembahan Senopati Bantul. Laporan diagnosa Unit Rawat Jalan RSD Panembahan Senopati 
Bantul. Bantul: Bagian Rekam Medis RSUD Panembahan Senopati Bantul; 2015.

8. Ngaisyah D. Hubungan pola makan dengan tingkat gula darah anggota DPRD Propinsi Kalimantan Timur. J Med Respati. 2015;10(2):35-47.

9. Listiana N, Mulyasari I, Paundrianagari M. Hubungan asupan karbohidrat sederhana dan aktivitas fisik dengan kadar glukosa darah pada penderita diabetes mellitus tipe 2 wanita usia 45-55 tahun di Kelurahan Gedawang Kecamatan Banyumanik Kota Semarang. J Gizi dan Kesehat. 2015;7(13):1-13.

10. Widya S. Konseling gizi mempengaruhi kualitas diet pasien diabetes mellitus tipe 2 di RSUP Dr. Sardjito Yogyakarta. J Gizi dan Diet Indones. 2015;3(1):31-40. 